\title{
Path Analysis on the Life-Course Biopsychosocial Determinants of Stunting in Children Under Five Years of Age in Karawang, West Java
}

\author{
Rona Luthfi Fauziyyah'), Yulia Lanti Retno Dewi'), CSP Wekadigunawan²), \\ Rita Benya Adriani \\ 1)Masters Program in Public Health, Universitas Sebelas Maret \\ 2)Faculty of Medicine, Universitas Sebelas Maret \\ 3)School of Health Polytechnics Surakarta, Central Java
}

\begin{abstract}
Background: Studies have shown that stunted children are more likely to start school later, perform more poorly on cognitive functioning tests, and are more likely to drop out of school. In future, adults who are stunted as children earn 20\% less than comparable adults who were not stunted and are 30\% more likely to live in poverty and less likely to work in skilled labor. This study aimed to examine the life-course biopsychosocial determinantsof stunting in children under five years of agein Karawang, West Java, using a path analysis model.

Subjects and Method: This was a case control study carried out inTunggakjati, Rengasdengklok, Kutawaluya, Pedes, and Medangasem community health centers, Karawang, West Java, from April to May 2018. A sample of 225 children under five was selected for this study by fixed disease sampling, consisting of 75 stunted children and 150 normal children. The dependent variable was stunting. The independent variables were maternal height, maternal middle upper arm circumference (MUAC), low birthweight (LBW), history of infection illness, maternal education, exclusive breastfeeding, complementary feeding, and family support. Child height was measured by infantometer or microtoice. The other variables were measured by questionnaire. The data were analyzed by path analysis run on Stata 13 .

Results: Stunting increased with LBW ( $b=1.64 ; 95 \% \mathrm{CI}=0.69$ to $2.59 ; \mathrm{p}=0.001)$ and history of infection illness ( $\mathrm{b}=1.80 ; 95 \% \mathrm{CI}=0.94$ to $2.67 ; \mathrm{p}<0.001)$. Stunting decreased with maternal height $\geq 150 \mathrm{~cm}(\mathrm{~b}=-1.57 ; 95 \% \mathrm{CI}=-2.43$ to $-0.71 ; \mathrm{p}<0.001)$ and appropriate complementary feeding $(\mathrm{b}=-$ $1.80 ; 95 \% \mathrm{CI}=-2.53$ to -1.08 ; $\mathrm{p}<0.001$ ). Stunting was indirectly affected by maternal MUAC, maternal education, exclusive breastfeeding, and family support.

Conclusion: Stunting increases with LBW and history of infection illness, but decreases with maternal height $\geq 150 \mathrm{~cm}$ and appropriate complementary feeding. Stunting is indirectly affected by maternal MUAC, maternal education, exclusive breastfeeding, and family support.
\end{abstract}

Keywords: stunting, life-course, biopsychosocial, children under five

\section{Correspondence:}

Rona Luthfi Fauziyyah. Masters Program in Public Health, Universitas Sebelas Maret. Jl. Ir. Sutami No. 36 A, Surakarta 57126, Central Java. Email: rona.luthfi@gmail.com.

Mobile: +6281316970696

\section{BACKGROUND}

$\overline{\text { Qualified resources have been determined }}$ since the first 1000 days of life. During this time, new individuals will experience a very optimal process of growth and development. If it is not supported with adequate nutrition, it is susceptible to stunting to effect irreversible on physical growth and also the cognitive development (Hardinsyah, 2016).

Stunting is one of three nutritional problems that occur globally. Stunting conditions illustrate the existence of chronic nutritional problems in the long 
term (UNICEF, 2013). According to data from the World Health Organization (WHO) in 2017, there were $22 \%$ of stunting toddlers worldwide. The results of nutritional status monitoring (PSG) in 2017 noted the prevalence of stunting toddlers in Indonesia which increased to $29.6 \%$ consisting of $19.8 \%$ stunted and $9.8 \%$ severely stunted, it experienced an increase compared to the previous year. Karawang is one of the thirteen priority districts / cities with intervention of stunting children in West Java, with the prevalence of stunting under five according to the 2017 PSG results of $26.1 \%$.

Stunting can be caused by multidimensional factors including biopsychosocial factors that occur throughout the life cycle (Kliegman et al., 2016; Murti, 2016). The purpose of this study was to analyze the lifelong biopsychosocial determinants of the incidence of stunting in children under five in Karawang, West Java.

\section{SUBJECTS AND METHOD \\ 1. Study Design \\ This was an analytic observational study with a case control design. The study was conducted in Karawang, West Java, from April to May 2018.}

\section{Population and Samples}

The target population in this study was all children under five years of age. The source population was children aged 12-59 months in Tunggakjati, Rengasdengklok, Kutawaluya, Pedes, and Medangasem community health centers. A sample of 225 children was selected by fixed disease sampling, comprising 75 stunted children and 150 normal children.

\section{Study Variables}

The dependent variable was stunting. The independent variables were maternal height, maternal middle upper arm circumference (MUAC), low birth weight (LBW), history of infectious disease, family support, maternal education, exclusive breastfeeding, and complementary feeding.

\section{Operational Definition of Variables} Stunting was defined as nutritional status in children aged 12-59 months based on the results of height for age measurement. It was categorized according to anthropometric standard based on the Decree of the Minister of Health of the Republic of Indonesia in 2010. Data on body length (children at aged under 2 years) was measured by infantometer. Body height was measured by microtoise. The measurement scale was continous, but for the purpose if data analysis, it was transformed into dichotomous, coded o for normal children and 1 for stunted children.

Maternal height was defined as the result of the measurement of the mother's height during pregnancy. The data were collected by maternal and child health monitoring book. The measurement scale was continous, but for the purpose if data analysis, it was transformed into dichotomous, coded o for $<150 \mathrm{~cm}$ and 1 for $\geq 150$ $\mathrm{cm}$.

Maternal MUAC was defined as the result of measuring the upper arm circumference of the mother during pregnancy as measured by circling the MUAC tape in the middle of the acromion (shoulder tip) and oligonone (elbow) in units of centimeters (cm). The data were collected by maternal and child health monitoring book. The measurement scale was continous, but for the purpose if data analysis, it was transformed into dichotomous, coded $\mathrm{o}$ for $\geq 23.5 \mathrm{~cm}$ and 1 for $<23.5$.

LBW was defined as infant birth weight which was weighed immediately after birth using infant weight scale. The data were collected by maternal and child health monitoring book. The measurement scale was continous, but for the purpose if 
data analysis, it was transformed into dichotomous, coded $\mathrm{o}$ for $\geq 2,500 \mathrm{~g}$ and 1 for $<2,500 \mathrm{~g}$.

History of infectious diseases was defined as an infectious disease that has been or is being suffered by children, including diarrhea or respiratory infection in the past six months. The data were collected by questionnaire. The measurement scale was categorical, coded o for no and 1 for yes.

Family support was defined as the interaction of family members (spouse/ husband, biological mother, mother-in-law) which gives rise to caring, compassion, giving attention, appreciation and assistance in the form of information, assessment, instrumental, and emotional which aims to facilitate the mother in carrying out her role caring for children, measured using a questionnaire. The data were collected by questionnaire. The measurement scale was continous, but for the purpose if data analysis, it was transformed into dichotomous, coded o for weak and 1 for strong.

Maternal education was defined as the highest level of formal education completed by mother. The data were collected by questionnaire. The measurement scale was categorical, coded o for $<$ senior high school and 1 for $\geq$ senior high school.

Exclusive breastfeeding was defined as a condition where children only get breast milk in the first 6 months of life without additional food or other drinks (including water, honey, formula milk, and fruit) except drugs. The data were collected by questionnaire. The measurement scale was categorical, coded o for no and 1 for yes.

Complementary feeding was defined as a condition where children eat food or other drinks as a companion or nutritional supplement rather than a substitute for breast milk for the first time. The data were collected by questionnaire. The measurement scale was continuous, but for the purpose if data analysis, it was transformed into dichotomous, coded o for inappropriate and 1 for appropriate.

\section{Data Analysis}

The data were analyzed by path analysis run on Stata 13 program to determine the relationship of independent variables to the dependent variable and find out the magnitude of the relationship on these variables.

\section{Research Ethics}

The research ethics includes informed consent, anonymity, confidentiality and ethical clearance. The ethical clearance of this study was carried out by Research Ethics Commission of Dr. Moewardi hospital, Surakarta. It has been declared ethically eligible based on a decree number: 483 / IV / HREC / 2018.

\section{RESULTS}

\section{Characteristics of Subjects}

Table 1 shows that the characteristics of children under five are $>24$ months old, namely 179 subjects or $79.6 \%$. As many as 125 study subjects (55.6\%) were female.

The characteristics of maternal age are mostly less than 35 years, which are 178 subjects or $79.1 \%$. Most of the study subjects (50.2\%) had family income $<\mathrm{Rp}$ 2,100,000 per month.

Table 1. Study Subject Characteristics

\begin{tabular}{|c|c|c|}
\hline Variable & $\mathbf{N}$ & (\%) \\
\hline \multicolumn{3}{|l|}{ Children Age } \\
\hline$<24$ months & 46 & 20.4 \\
\hline$\geq 24$ months & 179 & 79.6 \\
\hline \multicolumn{3}{|l|}{ Gender } \\
\hline Male & 100 & 44.4 \\
\hline Female & 125 & 55.6 \\
\hline \multicolumn{3}{|l|}{ Maternal Age } \\
\hline < 35 years old & 178 & 79.1 \\
\hline$\geq 35$ years old & 47 & 20.9 \\
\hline \multicolumn{3}{|l|}{ Family Income } \\
\hline$<\mathrm{Rp} 2,100,000$ & 113 & 50.2 \\
\hline$\geq \mathrm{Rp} 2,100,000$ & 112 & 49.8 \\
\hline
\end{tabular}




\section{Univariate Analysis}

Description of univariate analysis explains the general description of the data from each variable, including maternal height, maternal MUAC, LBW, history of infectious diseases, family support, education, exclusive breastfeeding, complementary feeding, and incidence of stunting.

Table 2. Univariate Analysis

\begin{tabular}{|c|c|c|}
\hline & $\mathbf{N}$ & (\%) \\
\hline \multicolumn{3}{|l|}{ Maternal height } \\
\hline$<150 \mathrm{~cm}$ & 42 & 18.7 \\
\hline$\geq 150 \mathrm{~cm}$ & 183 & 81.3 \\
\hline \multicolumn{3}{|l|}{ Maternal MUAC } \\
\hline$<23.5 \mathrm{~cm}$ & 66 & 29.3 \\
\hline $\begin{array}{l}\geq 23.5 \mathrm{~cm} \\
\text { LBW }\end{array}$ & 159 & 70.7 \\
\hline$\geq 2500 \mathrm{~g}$ & 189 & 84.0 \\
\hline$<2500 \mathrm{~g}$ & 36 & 16.0 \\
\hline \multicolumn{3}{|l|}{ History of Infectious } \\
\hline Disease & 178 & 79.1 \\
\hline $\begin{array}{l}\text { No } \\
\text { Yes }\end{array}$ & $\begin{array}{l}1,0 \\
47\end{array}$ & 20.9 \\
\hline \multicolumn{3}{|l|}{ Family Support } \\
\hline Weak & 101 & 44.9 \\
\hline Strong & 124 & 55.1 \\
\hline \multicolumn{3}{|l|}{ Maternal Education } \\
\hline$\geq$ senior high school & 95 & 42.2 \\
\hline \multicolumn{3}{|l|}{ Exclusive Breastfeeding } \\
\hline No & 86 & 38.2 \\
\hline & 139 & 62.2 \\
\hline \multicolumn{3}{|l|}{ Complementary Feeding } \\
\hline Inappropriate & 85 & 37.8 \\
\hline Appropriate & 139 & 62.2 \\
\hline \multicolumn{3}{|l|}{ Stunting } \\
\hline Normal & 150 & 66.7 \\
\hline Stunting & 75 & $33 \cdot 3$ \\
\hline
\end{tabular}

Table 2 shows that of the 225 study subjects, most mothers had a height of $>150 \mathrm{~cm}(81.3 \%)$, maternal pregnancy at $>23.5 \mathrm{~cm}(70.7 \%)$, toddlers with birth weight> 2500 grams $(84.0 \%)$, toddlers did not have history of diarrhea and ARI in the last 6 months (79.1\%), mothers with high family support (55.1\%), mothers with low education (57.8\%), children under five received exclusive breastfeeding (62.2\%), and the first administration of MP-ASI on time (62.2\%) ) Toddlers who experienced stunting were 75 toddlers (33.3) and nonstunting alites for about 150 children (66.7\%).

\section{Bivariate Analysis}

Bivariate analysis was used to see the correlation of independent variables (maternal height, maternal MUAC during pregnancy, LBW, history of infectious disease, family support, maternal education, exclusive breastfeeding, and first administration of MP-ASI) and the local variables (incidence of stunting ).

Table 3 shows that maternal height, maternal MAUC, LBW, history of infectious disease, family support, maternal education, exclusive breastfeeding, and complementary feeding had a statistical significant effect on the incidence of stunting.

\section{Path Analysis}

Table 4 shows the association between independent variables and dependent variable directly and indirectly. The risk of stunting in children under five was directly and positively affected by LBW $(b=1.64$; $95 \% \mathrm{CI}=0.69$ to $2.59 ; \mathrm{p}=0.001)$ and history of infectious disease $(\mathrm{b}=1.80$; $95 \%$ $\mathrm{CI}=0.94$ to 2.67 ; $\mathrm{p}<0.001$ ).

The risk of stunting in children under five was directly and negatively affected by maternal height $\geq 150 \mathrm{~cm}(\mathrm{~b}=-1.57 ; 95 \%$ $\mathrm{CI}=-2.43$ to $-0.71 ; \mathrm{p}<0.001)$, and appropriate complementary feeeding $(\mathrm{b}=-1.8 \mathrm{o}$; $95 \% \mathrm{CI}=-2.53$ to $-1.08 ; \mathrm{p}<0.001$ ).

The risk of stunting in children under five was indirectly affected by maternal MUAC, maternal education, family income, and exclusively breasfeeding.

LBW decreased with maternal MUAC

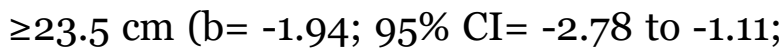
$\mathrm{p}<0.001)$ and strong family support $(\mathrm{b}=-$ $1.47 ; 95 \% \mathrm{CI}=-2.39$ to $-0.55 ; \mathrm{p}=0.002$ ). 
History of infectious diseases among children reduced by high maternal education $(b=-0.71 ; 95 \% \mathrm{CI}=-1.45$ to 0.04 ; $\mathrm{p}=0.063)$ and strong family support $(\mathrm{b}=-$ 0.93; 95\% CI= -1.63 to $-0.24 ; \mathrm{p}=0.008$ ).

Appropriate complementary feeding increased with high maternal education $(b=$ 1.26; $95 \% \mathrm{CI}=0.55$ to $1.97 ; \mathrm{p}<0.001)$, exclusive breastfeeding $(\mathrm{b}=1.94 ; 95 \% \mathrm{CI}=$
1.27 to $2.61 ; \mathrm{p}<0.001$ ), and strong family support $(\mathrm{b}=0.72 ; 95 \% \mathrm{CI}=0.04$ to $1.39 ; \mathrm{p}=$ o.037).

Exclusive breastfeeding increased with high maternal education $(b=0.81$; $95 \% \mathrm{CI}=0.20$ to $1.42 ; \mathrm{p}=0.010)$ and strong family support $(b=1.28 ; 95 \% \mathrm{CI}=0.69$ to $1.87 ; \mathrm{p}<0.001)$.

Table 3. Bivariate analysis of life-course biopsychosocial determinants on stunting

\begin{tabular}{|c|c|c|c|c|c|c|c|c|}
\hline \multirow{3}{*}{ Independent Variable } & \multicolumn{4}{|c|}{ Stunting } & \multirow{3}{*}{ OR } & \multicolumn{2}{|c|}{$95 \% \mathrm{CI}$} & \multirow{3}{*}{$\mathbf{p}$} \\
\hline & \multicolumn{2}{|c|}{ No } & \multicolumn{2}{|c|}{ Yes } & & \multirow{2}{*}{$\begin{array}{l}\text { Lower } \\
\text { limit }\end{array}$} & \multirow{2}{*}{$\begin{array}{l}\text { Upper } \\
\text { limit }\end{array}$} & \\
\hline & $\mathbf{n}$ & $\%$ & $\mathbf{n}$ & $\%$ & & & & \\
\hline \multicolumn{9}{|l|}{ Maternal height } \\
\hline$<150 \mathrm{~cm}$ & 16 & 38.1 & 26 & 61.9 & 0.22 & 0.11 & 0.46 & $<0.001$ \\
\hline $\begin{array}{l}\geq 150 \mathrm{~cm} \\
\text { Maternal MUAC }\end{array}$ & 134 & 73.2 & 49 & 26.8 & & & & \\
\hline$<23.5 \mathrm{~cm}$ & 14 & 21.2 & 52 & 78.8 & 0.05 & 0.02 & 0.10 & $<0.001$ \\
\hline $\begin{array}{l}\geq 23.5 \mathrm{~cm} \\
\mathbf{L B W}\end{array}$ & 136 & $85 \cdot 5$ & 23 & 14.5 & & & & \\
\hline$\geq 2500 \mathrm{~g}$ & 140 & 74.1 & 49 & $25 \cdot 9$ & 7.43 & $3 \cdot 34$ & 16.51 & $<0.001$ \\
\hline$<2500 \mathrm{~g}$ & 10 & 27.8 & 26 & 72.2 & & & & \\
\hline \multicolumn{9}{|l|}{$\begin{array}{l}\text { History of infectious } \\
\text { disease }\end{array}$} \\
\hline No & 137 & 77.0 & 41 & 23.0 & 8.74 & 4.22 & 18.10 & $<0.001$ \\
\hline Yes & 13 & 27.7 & 34 & 72.3 & & & & \\
\hline \multicolumn{9}{|l|}{ Family support } \\
\hline Low & 45 & 44.6 & 56 & 55.4 & 0.14 & 0.08 & 0.27 & $<0.001$ \\
\hline High & 105 & 84.7 & 19 & 15.3 & & & & \\
\hline \multicolumn{9}{|l|}{ Maternal education } \\
\hline Low & 71 & 54.6 & 59 & 45.4 & 0.24 & 0.13 & 0.46 & $<0.001$ \\
\hline High & 79 & 83.2 & 16 & 16.8 & & & & \\
\hline \multicolumn{9}{|l|}{ Exclusive breastfeeding } \\
\hline No & 35 & 40.7 & 51 & 59.3 & 0.14 & 0.08 & 0.26 & $<0.001$ \\
\hline Yes & 115 & 82.7 & 24 & $17 \cdot 3$ & & & & \\
\hline \multicolumn{9}{|l|}{ Complementary feeding } \\
\hline Not on time & 33 & 38.8 & 52 & 61.2 & 0.12 & 0.07 & 0.46 & $<0.001$ \\
\hline On time & 117 & 83.6 & 23 & 16.4 & & & & \\
\hline
\end{tabular}

\section{DISCUSSION}

\section{The relationship between maternal height and stunting}

The results of the analysis showed that maternal height had a statistically significant effect on the incidence of stunting $(b=-1.57 ; 95 \% \mathrm{CI}=-2.43$ to -0.71 ; $\mathrm{p}<0.001)$. This shows that mothers who have a height of $>150 \mathrm{~cm}$ reduce the risk of stunts by 1.57 times compared to children of mothers who have a height of $<150 \mathrm{~cm}$. The results of this study are in line with the research of Addo et al. (2013), which states that short mothers $(<150 \mathrm{~cm})$ are more likely to have children who are stunting in the first 2 years. Stunting events continue to be passed on to the next generation because maternal height was one of the genetic factors that played a role as the 
Journal of Maternal and Child Health (2019), 4(1): 25-35

https://doi.org/10.26911/thejmch.2019.04.01.04

basis of achieving a child's growth and development.Walker et al. (2015) added thatstunting mothers significantly gave birth to stunting children and toddlers with lower cognitive abilities. Intergenerational intervention would be maximized if it was applied for the first 1000 days of life, which was the pregnancy period up to the first 2 years of birth.

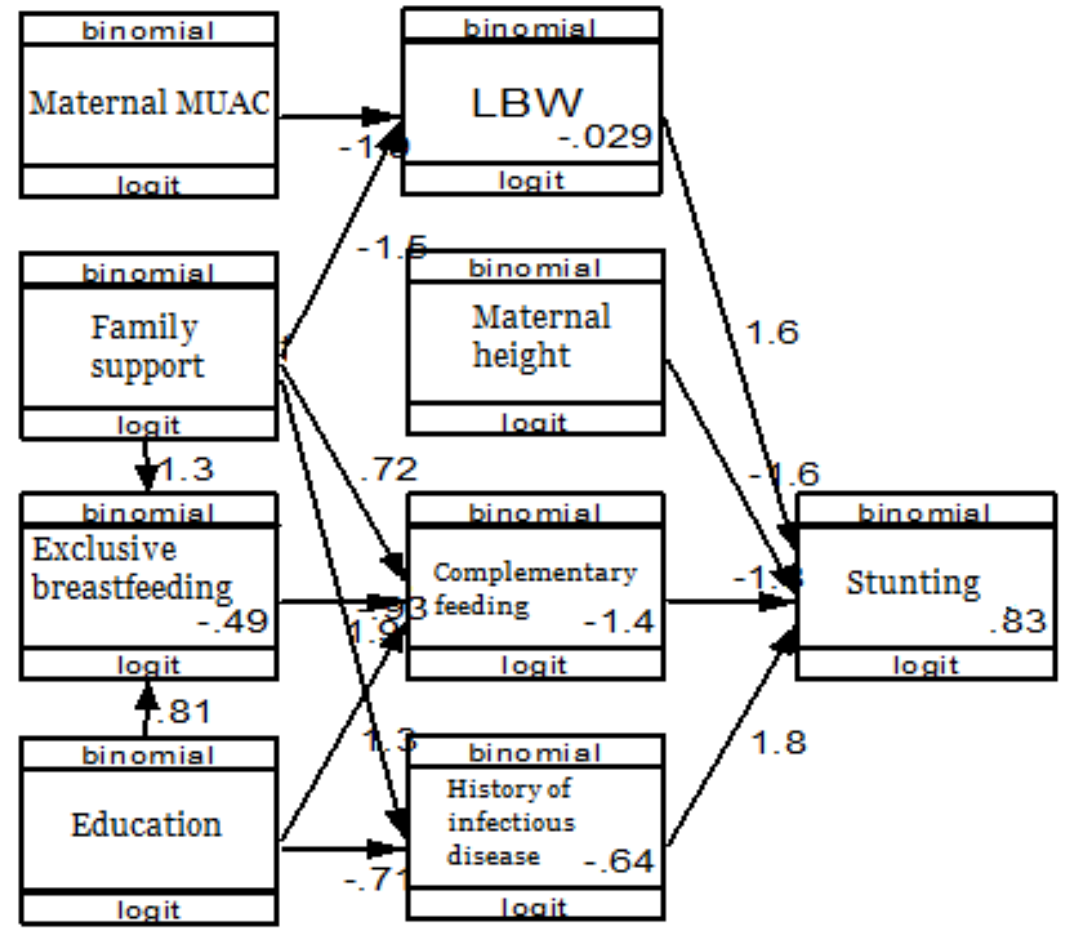

Figure 1. Structural Model of Path Analysis with Estimation

Table 4. The Results of Path Analysis

\begin{tabular}{|c|c|c|c|c|c|c|}
\hline \multirow[b]{2}{*}{ Dependent Variable } & \multirow{2}{*}{\multicolumn{2}{|c|}{ Independent variable }} & \multirow[b]{2}{*}{$\mathbf{b}$} & \multicolumn{2}{|c|}{$95 \% \mathrm{CI}$} & \multirow[b]{2}{*}{$\mathbf{p}$} \\
\hline & & & & $\begin{array}{c}\text { Lower } \\
\text { Limit }\end{array}$ & $\begin{array}{l}\text { Upper } \\
\text { Limit }\end{array}$ & \\
\hline Direct Effect & & & & & & \\
\hline Stunting & $\leftarrow$ & Maternal height & -1.57 & -2.43 & -0.71 & $<0.001$ \\
\hline Stunting & $\leftarrow$ & LBW & 1.64 & 0.69 & 2.59 & 0.001 \\
\hline Stunting & $\leftarrow$ & History of infectious disease & 1.80 & 0.94 & 2.67 & $<0.001$ \\
\hline Stunting & $\leftarrow$ & Complementary feeding & -1.80 & -2.53 & -1.08 & $<0.001$ \\
\hline Indirect Effect & & & & & & \\
\hline LBW & $\leftarrow$ & Maternal MUAC & -1.95 & -2.78 & -1.11 & $<0.001$ \\
\hline LBW & $\leftarrow$ & Family Support & -1.47 & -2.39 & -0.55 & 0.002 \\
\hline $\begin{array}{l}\text { History of infectious } \\
\text { disease }\end{array}$ & $\leftarrow$ & Maternal Education & -0.71 & -1.45 & 0.04 & 0.063 \\
\hline $\begin{array}{l}\text { History of infectious } \\
\text { disease }\end{array}$ & $\leftarrow$ & $\begin{array}{l}\text { History of Infectious } \\
\text { Disease }\end{array}$ & -0.93 & -1.63 & -0.24 & 0.008 \\
\hline Complementary feeding & $\leftarrow$ & Maternal Education & 1.26 & 0.55 & 1.97 & $<0.001$ \\
\hline Complementary feeding & $\leftarrow$ & Exclusive Breastfeeding & 1.94 & 1.27 & 2.61 & $<0.001$ \\
\hline Complementary feeding & $\leftarrow$ & Family Support & 0.72 & 0.04 & 1.39 & 0.037 \\
\hline Exclusive breastfeeding & $\leftarrow$ & Maternal Education & 0.81 & 0.20 & 1.42 & 0.010 \\
\hline $\begin{array}{l}\text { Exclusive breastfeeding } \\
\text { n Observation }=225 \\
\text { Log likelihood }=-522.06\end{array}$ & $\leftarrow$ & Family Support & 1.28 & 0.69 & 1.87 & $<0.001$ \\
\hline
\end{tabular}




\section{The relationship between maternal MUAC on stunting}

The result of analysis showed that maternal MUAC through LBW has an effect on the incidence of stunting $(b=-1.94 ; 95 \% \mathrm{CI}=-$ 2.78 up to $-1.11 ; \mathrm{p}<0.001)$. The result of this study was in line with a study by Viridula et al. (2016), which stated that normal maternal MUAC decreased the incidence of stunting through LBW by 4 times.

Most mothers $(78.8 \%)$ of stunting toddlers had MUAC of $<23.5 \mathrm{~cm}$. Maternal nutritional status before and during pregnancy affected the quality of the baby, success in breastfeeding, and child growth (Rahayu et al., 2016). One assessment of nutritional status that was easy to do was to measure the upper arm circumference (MUAC), so that it could indicate whether the mother was experiencing lack of chronic energy (LCE) or not. The supplementation strategies for supplementary feeding (SF) for pregnant women aimed at improving maternal nutritional status during pregnancy and give birth to quality children (Ministry of Health RI, 2017).

\section{The relationship between LBW on stunting}

The result of analysis showed that LBW has an effect on the incidence of stunting which was statistically significant $(b=1.64 ; 95 \%$ $\mathrm{CI}=0.69$ to $2.59 ; \mathrm{p}=0.001)$. This showed that infants with a birth weight <2500 grams increased the risk of stunting by 1.64 times compared to infants with birth weight $>2500$ grams.

The result of this study was in line withAryastami et al. (2017), who stated thatthe incidence of LBW increased the risk of stunting in children aged 12-23 months old by 1.74 times. Low birth weight incident was related to premature birth, intra uterine growth retardation, or both. Generally, in developing countries like Indonesia, LBW was caused by IUGR. This indicated that there was an obstacle of growth in the uterus which could adversely affect and even caused permanent damage after birth including less optimal height (Zohdi et al., 2012).

\section{The relationship between history of infectious disease on stunting}

The result of analysis showed that history of infectious disease has an effect on the incidence of stunting which was statistically significant $(b=1.80 ; 95 \% \mathrm{CI}=0.94$ to 2.67; $\mathrm{p}<0.001)$. This showed that toddlers who have a history of diarrhea or pneumonia in the last 6 months increased the risk of stunting by 1.80 times compared to toddlers who did not have infectious diseases.

The result of this study was in line witha study by Namangboling et al. (2017), which stated thathistory of infectious diseases was the dominant factor in determining children'snutritional status. The presence of infectious diseases caused a decrease in appetite which resulted in a decrease in health conditions and children nutritional status. Akombi et al. (2017), stated thatthe occurrence of fever and recurrent diarrhea affected the nutrients that should be used as growth and development, which caused growth failure including the risk of stunting.

\section{The relationship between family support on stunting}

The result of analysis showed that family support through LBW has an effect on the incidence of stunting $(b=-1.47 ; 95 \% \mathrm{CI}=-$ 2.39 to $-0.55 ; \mathrm{p}=0.002)$. This showed that mothers who have high family support were 1.47 times less likely to have babies with LBW compared to mothers with lack of family support. The result of this study was in line with a study byViridula et al.(2016), which stated thatmothers who have strong family support were 0.52 time more likely 
to deliver a baby with birth weight $\geq 2500$ gram.

The result of analysis showed that family support through history of infectious disease has an effect on the incidence of stunting ( $b=-0.93 ; 95 \% \mathrm{CI}=-1.63$ to -0.24 ; $\mathrm{p}=0.008$ ). This showed that mothers who have high family supportwere 0.93 time less likely to have history of infectious diseases compared to mothers with lack of family support.Psychosocial factors were closely related to problems that occur in human's life, not to mention health problems. Mothers who got lack of family support were more likely to experience stress or depression after gave birth which affected child care (Upadhyay and Srivastava, 2016).

The result of analysis showed that family support through first complementary feeding has an effect on the incidence of stunting $(\mathrm{b}=0.72 ; 95 \% \mathrm{CI}=0.04$ up to 1.39; $\mathrm{p}=0.037$ ).This showed that mothers who have high family support were 0.72 time more likely to give complementary food on time compared to mothers who got lack of family support.The accuracy of the first complementary feeding was affected by education or knowledge from the family as the closest people to the mother. The family type also affected the maternal authority in deciding how to take care of their children, including the provision of nutrition (Rao et al., 2011).

The result of analysis showed that family support through exclusive breastfeeding has an effect on the incidence of stunting ( $\mathrm{b}=1.28 ; 95 \% \mathrm{CI}=0.69$ up to 1.87 ; $\mathrm{p}<0.001)$.This showed that mothers who have high family support were 1.28 times more likely to give exclusive breastfeeding compared to mothers with lack of family support. The result of this study was in line with a study by Fahriani et al. (2014), which stated that family support increased exclusive breastfeeding in infants $(\mathrm{OR}=$ 6.25 ; $95 \%$ CI: 1.92 to $20.35 ; \mathrm{p}=0.002$ ). Breastfeeding played an important role in the health, growth, and development of babies. A mother would need help from the closest person to run and through the difficulties while breastfeed her baby. The presence of the husband and baby's grandmother was often regarded as one of the factors that could affect the process of breastfeeding, however, it was the support and active involvement of the family that actually contributed to changes in the sustainable behavior of mothers in the breastfeeding process (Horii et al., 2017).

\section{The relationship between maternal education on stunting}

The result of analysis showed that maternal education through history of infectious diseases has an effect on the incidence of stunting $(b=-0.71 ; 95 \% \mathrm{CI}=-1.45$ to 0.04 ; $\mathrm{p}=0.063)$. This showed that toddlers with highly-educated mothers decreased the risk by 0.71 time to have history of infectious diseases than toddlers with low-educated mothers. The result of this study was in line with a study bySinmegnet al. (2014) and Luthfiyana (2018), which stated that toddlers with low-educated mothers were 1.81 times more likely to have diarrhea and o.81 time more likely to experience pneumoniathan toddlers who have highlyeducated mothers.

The result of analysis showed that maternal education through exclusive breastfeeding has an effect on the incidence of stunting $(\mathrm{b}=0.81 ; 95 \% \mathrm{CI}=0.20$ up to 1.42; $\mathrm{p}=0.010$ ). this showed that highlyeducated mothers were 0.81 time more likely to give exclusive breastfeeding than low-educated mothers. The result of this study was in line with a study byAcharya and Khanal (2015), which stated that mothers with middle or high level of education increased the risk of exclusive 
breastfeeding and early breastfeeding initiation was higher than mothers with low level of education.

The result of analysis showed that maternal education through first complementary feeding has an effect on the incidence of stunting $(b=1.26 ; 95 \% \mathrm{CI}=0.55$ up to $1.97 ; \mathrm{p}<0.001$ ). This showed that highlyeducated mothers were 1.26 times more likely to give first complementary food on time than mothers with low level of education. The introduction of complementary food at the age of 6 months old was the right time to complete the nutritional needs beside breastmilk. The introduction of complementary food must be considered carefully, if it was too early (before 6 months), it could disturb the baby's respiratory tract or exposure to microbes which contained in unhygienic food or drinks. If it was delayed (more than 6 months), it could lead to lack of food intake, delays in the development of eating behavior, and oral motor skills (chewing, swallowing, talking), even could lead to difficulties in eating(Saleem et al., 2014). According to Yılmaz et al. (2017), giving nutrition to children would be more effective if both partners have a high level of education and mothers joined the classes for pregnant women to increase their knowledge and prepare for breastfeeding.

\section{The relationship between exclusive breastfeeding and complementary feeding on stunting}

The result of analysis showed that exclusive breastfeeding through first complementary feeding has an effect on the incidence of stuntingand it was statistically significant (b=1.94; 95\% $\mathrm{CI}=1.27$ up to $2.61 ; \mathrm{p}<0.001$ ). This showed that toddlers who got exclusive breastfeeding were 1.94 times more likely to get complementary food than toddlers who did not get exclusive breastfeeding. In this study, most subjects gave exclusive breastfeeding (62.8\%) and first complementary food on time (62.2\%). This was in line withSeptiani (2014)who stated thatthe low level of exclusive breastfeeding was inversely proportional to the high risk of early breastfeeding (infants aged $<6$ months old).

WHO recommended the time to exclusively breastfeed the infants up to the first 6 months and continue with appropriate complementary foods. However, globally only $40 \%$ of babies under 6 months old who received exclusive breastfeeding. This study revealed that exclusive breastfeeding was affected by family support and maternal education factors. Mensah et al. (2017) added thatthere were other factors that also affected exclusive breastfeeding which were maternal employment and maternal belief.

The result of analysis showed that first complementary feeding has an effect on the incidence of stuntingand it was statistically significant $(\mathrm{b}=-1.80 ; 95 \% \mathrm{CI}=-$ 2.53 to $-1.08 ; \mathrm{p}<0.001$ ). This showed that toddlers who received the first complementary food on time (at the age of 6 months old) reduced the risk of stunting by 1.80 times compared to toddlers who did not get first complementary food on time.

The first provision of complementary food also determined the nutritional status of a child, the result of this study was in line with Tessema et al. (2013), who stated thatbabies who did not get complementary food on time were 5.15 times more likely to have malnutrition compared to babies who got the complementary food on time.Good and proper nutrition intake was a prerequisite for achieving optimal health and development. Breastfeeding was the best method to fulfill the nutritional, metabolic, and psychological needs of babies. 


\section{REFERENCES}

Acharya P, Khanal V (2015). The effect of mother's educational status on early initiation of breastfeeding: Further analysis of three consecutive Nepal Demographic and Health Surveys Global health. BMC Public Health 15(1). doi: 10.1186/s12889-015-2405$\mathrm{y}$.

Addo OY, Stein A, Fall CH, Denise P, Gigante, Aravinda M, Guntupalli, et al (2013) Maternal height and child growth patterns. Journal of Pediatrics. Elsevier Ltd, 163(2), p. 549554.e1.

doi: 10.1016/j.jpeds.2013.02.002.

Akombi BJ, Kingsley EA, Dafna M, John JH, Andre MR (2017). Multilevel analysis of factors associated with wasting and underweight among children under-five years in Nigeria.Nutrients, 9(1). doi: 10.3390/nu9010044.

Aryastami NK, Anuraj S, Nunik K, Besral, Abas BJ, Endang A (2017). Low birth weight was the most dominant predictor associated with stunting among children aged 12-23 months in Indonesia. BMC Nutrition, 3(1), p. 16. doi: 10.1186/s40795-017-0130-X.

Fahriani R, Rohsiswatmo R, Hendarto A (2014). Faktor yang Memengaruhi Pemberian ASI Eksklusif pada Bayi Cukup Bulan yang Dilakukan Inisiasi Menyusu Dini (IMD).Sari Pediatri, 15(6): 394-402.

Hardinsyah SI (2016).Ilmu Gizi: Teori dan Aplikasi. Jakarta: EGC.

Horii, N. James A, Yves MP, Dominique W (2017). Determinants of early initiation of breastfeeding in rural Niger: Cross-sectional study of community based child healthcare promotion. International Breastfeeding Journal, 12(1): 1-10. doi: 10.1186/s13006-0170134-9.
Kemenkes RI (2018). Hasil Pemantaun Status Gizi dan Indikator Kinerja Gizi Tahun 2017. Jakarta: Direktorat Jenderal Kesehatan Masyarakat. (2017). Petunjuk Teknis Pemberian Makanan Tambahan. 1-44. Available at: http://gizi.depkes.go.id/wp-content/uploads/2017/o9/Juknis-PMT2017.pdf.

Kliegman RM, Stanton B, Geme JWSt, Schor NF, BR (2016).Nelson Textbook of Pediatricts. 2 (20). Pennsylvania: Elsevier Health Sciences.

Luthfiyana NU, Rahardjo SS, Murti B (2018). Multilevel Analysis on the Biological, Social Economic, and Environmental Factors on the Risk of Pneumonia in Children Under Five in Klaten, Central Java. Journal of Epidemiology and Public Health, 3: 128-142. https://doi.org/10.26911/jepublichealth.2018.03.02.03

Mensah KA, Enoch A, Francis OA, Paul O, Emmanuel AB, Rose OA (2017). Factors influencing the practice of exclusive breastfeeding among nursing mothers in a peri-urban district of Ghana. BioMed Central, 10(1): 1-7. doi: 10.1186/s13104-017-2774-7.

Murti B (2016).Prinsip dan Metode Riset Epidemiologi. Surakarta: Yuma Pustaka.

Namangboling AD, Murti B, Sulaeman ES (2017). Hubungan Riwayat Penyakit Infeksi dan Pemberian ASI Eksklusif dengan Status Gizi Anak Usia 7-12 Bulan di Kecamatan Kelapa Lima Kota Kupang. Sari Pediatri, 19(2): 9196.

Rahayu RM, Pamungkasari EP, Wekadigunawan CSP (2016). The Biopsychosocial Determinants of Stunting and Wasting in Children Aged 12-48 Months. Journal of Maternal and Child Health (2018), 3(2): 105- 
118.https://doi.org/10.26911/thejmch .2018.03.02.03

Rao S, Sawathi PM, Unnikrishnan B, Hedge A (2011). Study of complementary feeding practices among mothers of children aged six months to two years - A study from coastal south India.The Australasian medical journal, 4(5): 252-7. doi: 10.4066/AMJ.2011.607.

Saleem AF, Mahmud S, Ansari NB, Zaidi AKM (2014). Impact of Maternal Education about Complementary Feeding on Their Infants' Nutritional Outcomes in Low- and Middleincome Households: A Communitybased Randomized Interventional Study in Karachi, Pakistan. Journal of Health, Population and Nutrition, 32(4): 623-633. ISSN 1606-0997.

Septiani W (2014). Hubungan Pemberian Makanan Pendamping Asi Dini dengan Status Gizi Bayi o-11 Bulan di Puskesmas Bangko Rokan Hilir. Jurnal Kesehatan Komunitas, 2(4): 148-153.

Sinmegn MT, Asres AG, Shimeka TA (2014). Determinants of childhood diarrhea among underfive children in Benishangul Gumuz Regional State, North West Ethiopia.BMC Pediatrics. BMC Pediatrics, 14(1): 1-9. doi: 10.1186/1471-2431-14-102.

Tessema M, Belachew T, Ersino G (2013). Feeding patterns and stunting during early childhood in rural communities of Sidama South Ethiopia.Pan African Medical Journal, 14: 1-12. doi: 10.11604/pamj.2013.14.75.1630.

UNICEF (2013). Improving child nutrition: The achievable imperative for global progress.Division of Communication, UNICEF. 1-132. doi: 978-92-8064686-3.
Upadhyay AK, Srivastava S (2016). Effect of pregnancy intention, postnatal depressive symptoms and social support on early childhood stunting: Findings from India.BMC Pregnancy and Childbirth, 16(1): 1-14. doi: 10.1186/s12884-016-0909-9.

Viridula EY, Murti B, Suryani N (2016). Path Analysis on the Effect of Biopsychosocial and Economic Factors during Gestational Period on the Risk of Stunting and Development in Children under Five, in Nganjuk, East Java. Journal of Health Promotion and Behaviour. 1 (3): 180-189. https://doi.org/10.26911/thejhpb.2016.01.03.05

Walker SP, Chang SM, Wright A, Osmon C, McGregor SMG (2015). Early Childhood Stunting Is Associated with Lower Developmental Levels in the Subsequent Generation of Children. Journal of Nutrition, 145(4): 823828. doi: 10.3945/jn.114.200261.

World Health Organization (2017). Global Health Observatory Data.

Yllmaz E, Ocal FD, Yilmaz ZV, Cehyan M, Kara OF, Küçüközkan T (2017).Early initiation and exclusive breastfeeding: Factors influencing the attitudes of mothers who gave birth in a babyfriendly hospital. Turk Jinekoloji ve Obstetrik Dernegi Dergisi, 14(1): 1-9. doi: 10.4274/tjod.90018.

Zohdi V, Sutherland MR, Lim K, Gubhaju L, Zimanyi MA, Black MJ (2012). Low birth weight due to intrauterine growth restriction and/or preterm birth:Effects on nephron number and long-term renal health.International Journal of Nephrology. doi: 10.1155/2012/136942. 